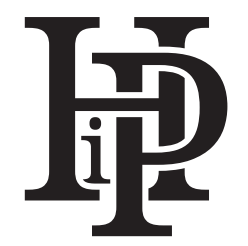

Historia i Polityka

Nr 35(42)/2021, ss. 109-126

www.hip.umk.pl (c) $\underset{\mathrm{a}}{\Theta} \Theta$

ISSN 1899-5160, e-ISSN 2391-7652

DOI: http://dx.doi.org/10.12775/HiP.2021.007

Zbigniew K L I M I U K

Instytut Pracy i Spraw Socjalnych, Warszawa, Polska

\title{
Ewolucja stosunków handlowych i umownych Polski z krajami EWG w latach 1960-1990
}

\section{Evolution of Poland's Trade and Contractual Relations with the EEC Countries in the Period 1960-1990}

\section{- Abstrakt •}

Artykuł analizuje kolejne etapy stosunków handlowych i umownych Polski z krajami EWG od momentu powstania tej organizacji. Stosunki Polski z EWG w latach 60. i 70. XX w. pozostawały pod dużym wpływem czynników politycznych. Mniejsza rola przypadała uwarunkowaniom ekonomicznym. W handlu WschódZachód występowały silne ograniczenia, m.in. strategiczne ograniczenia eksportowe, ograniczenia kredytowe oraz stosowane przez kraje EWG ograniczenia ilościowe importu z krajów socjalistycznych. Polskie kontakty z EWG, zwane w odróżnieniu od oficjalnych - technicznymi, rozpoczęły się w 1964 r. W handlu Wspólnoty Polska odgrywała historycznie niewielką rolę i nie miała dla EWG istotnego znaczenia. Udział Polski w globalnym imporcie państw Wspólnoty w 1988 r. wynosił tylko 0,23\%. Po podpisaniu w 1989 r. umowy handlowej między Polską a Wspólnotą Europejską rząd polski podjął starania o nawiązanie maksymalnie szerokiej współpracy z EWG.

\section{- Abstract •}

The article analyzes the successive stages of Poland's commercial and contractual relations with the EEC (European Economic Community) countries since the establishment of this organization. Poland's relations with the EEC in the 1960s and 1970s were strongly influenced by political factors. Economic conditions played a less important role. There were strong restrictions in the East-West trade, including strategic export restrictions, credit restrictions, and EEC quantitative restrictions on imports from socialist countries. Polish contacts with the EEC, known as the official-technical ones, began in 1964. In the trade of the Community, Poland played a historically insignificant role and had no significant importance for the EEC. The share of Poland in the global imports of the Community countries in 1988 was only $0.23 \%$. After the signing of a trade agreement between Poland and the European Community in 1989, the Polish government made efforts to establish maximum cooperation with the EEC. 
Słowa kluczowe: Traktat Rzymski; Europejska Wspólnota Gospodarcza; współpraca gospodarcza; stosunki handlowe i umowne; wspólna polityka handlowa; umowa o stowarzyszeniu; handel zagraniczny; warunki dostępu polskiego eksportu; ograniczenia eksportowe
Keywords: Treaty of Rome; European Economic Community; economic cooperation; trade and contractual relations; common trade policy; association agreement; foreign trade; access conditions for Polish exports; export restrictions

\section{Wstęp}

Powstanie Europejskiej Wspólnoty Gospodarczej (EWG) w 1958 r. nie przyniosło natychmiastowego uzgodnienia zasad i zastosowania wspólnej polityki handlowej wobec krajów trzecich, w tym także Polski. Do 1969 r. polityka handlowa była zasadniczo prowadzona przez każdy kraj EWG z osobna. Stosunki Wspólnoty z krajami socjalistycznymi (blokiem komunistycznym), w tym również z Polską, wyznaczały wieloletnie porozumienia o współpracy gospodarczej, przemysłowej i naukowo-technicznej. Obok nich istniały dwustronne umowy handlowe określające wielkość i strukturę obrotów między poszczególnymi państwami, ilości dozwolonego importu w grupach towarowych poddanych ograniczeniom ilościowym w danym kraju EWG oraz zasady przyznawania sobie Klauzuli Najwyższego Uprzywilejowania (KNU). Takie dwustronne umowy handlowe Polska zawarła ze wszystkimi ówczesnymi krajami EWG.

Stosunki Polski ze Wspólnotą w latach 60. pozostawały pod dużym wpływem czynników politycznych, o czym decydowała ogólna sytuacja polityczna na świecie. Mniejsza rola przypadała ekonomicznym uwarunkowaniom stosunków EWG-Polska. W handlu Wschód-Zachód występowały silne ograniczenia, m.in. strategiczne ograniczenia eksportowe (lista COCOM), ograniczenia kredytowe (postanowienia Unii Berneńskiej) oraz stosowane przez kraje EWG ograniczenia ilościowe importu z krajów socjalistycznych (Balassa, 1962). Polskie kontakty z EWG, zwane w odróżnieniu od oficjalnych - technicznymi, rozpoczęły się w 1964 r. Początkowo przez przedstawicielstwa przy GATT, a następnie poprzez Biuro Radcy Handlowego w Brukseli z Generalną Dyrekcją Rolnictwa i Generalną Dyrekcją Stosunków Zewnętrznych Komisji EWG. Merytorycznie pierwszy temat był związany z problematyką wspólnej polityki rolnej i dotyczył eksportu z Polski jaj do Wspólnoty. W dniu 7 kwietnia 1965 r. przedstawiciele Polski i EWG przy GATT w Genewie podpisali odpowiednie porozumienie. Było to pionierskie wśród krajów RWPG nawiązanie kontaktów z Komisją EWG (Balassa, 1968). Podobne porozumienia między naszym krajem a Wspólnotą dotyczące polskiego eksportu bitych kurcząt, kaczek i gęsi oraz bitych indyków zostały podpisane 
w latach 1968 oraz 1970. Przedmiotem wszystkich trzech zawartych porozumień było zwolnienie wywozu wymienionych towarów do EWG z dodatkowej opłaty wyrównawczej w zamian za udzielenie przez nasz kraj gwarancji, że przy ich eksporcie na obszar EWG właściwe przedsiębiorstwa nie będą sprzedawać poniżej ustalonej przez EWG minimalnej ceny importowej (Łychowski, 1968). Należy zaznaczyć, że wymienione porozumienia nie miały charakteru umów rządowych i fakt ich podpisania nie mógł być interpretowany jako polityczne uznanie Wspólnoty przez Polskę.

Ten tekst analizuje kolejne etapy stosunków gospodarczych i handlowych między Polską a EWG w latach 1960-1990, tj. do momentu rozpoczęcia negocjacji o stowarzyszeniu Polski z EWG, a następnie negocjacji w sprawie członkostwa naszego kraju w Unii Europejskiej, następczyni EWG. Powstał on na bazie studiów literaturowych. Jego tezę można sformułować następująco: na przestrzeni ponad 30 lat relacji Polski z krajami EWG zauważalny był fakt coraz bardziej pogłębionej i zaawansowanej z upływem czasu współpracy gospodarczej i handlowej naszego kraju z tą organizacją gospodarczą.

\section{Okres dwustronnych umów handlowych}

W dniu 1 stycznia 1969 r. zakończył się tzw. okres przejściowy z EWG i wprowadzona została przez nią wspólna polityka handlowa wobec partnerów zewnętrznych. Oznaczało to, że umowy powinny być odtąd zawierane nie przez poszczególne kraje członkowskie EWG, ale przez odpowiednie instytucje Wspólnoty (Komisję i Radę EWG). W dniu 16 grudnia 1969 r. Rada EWG podjęła decyzję, że zasady wspólnej polityki handlowej będą mieć zastosowanie do krajów o państwowym handlu zagranicznym (Zabielski, 1968). W poprzedzającym okresie kraje socjalistyczne, w tym również Polska, miały umowy handlowe z poszczególnymi państwami członkowskimi EWG. W momencie ogłoszenia zasad wspólnej polityki handlowej większość z tych umów była nadal w mocy (Bożyk, 1972). W tej sytuacji EWG uznała w drodze wyjątku, że poszczególne państwa członkowskie EWG mają prawo zawierać i posiadać umowy handlowe do końca 1972 r. W każdym przypadku umowy te miały wygasnąć lub ulec rozwiązaniu do 31 grudnia $1974 \mathrm{r}$.

Opierając się na zasadach wspólnej polityki handlowej Rada EWG ogłosiła w maju 1974 r., że Wspólnota jest gotowa negocjować nowe umowy handlowe z każdym z państw socjalistycznych. W listopadzie 1974 r. Komisja EWG przygotowała ramowy projekt umowy handlowej. W projekcie tym znalazła się Klauzula 
Najwyższego Uprzywilejowania, a główne problemy handlowe zostały uregulowane na zasadzie niepreferencyjnego traktowania. Takie ramowe umowy rozesłano wówczas do wszystkich państw socjalistycznych jako propozycję do negocjacji. Działania te wówczas nie przyniosły rezultatu i listy pozostały bez odpowiedzi. Z państw socjalistycznych jedynie Chiny w 1978 r. zawarły taką umowę handlową. Ponieważ do porozumienia między EWG a państwami socjalistycznymi w 1974 r. nie doszło Komisja EWG zdecydowała, że warunki określające dostęp do rynku i inne postanowienia nie będą dłużej przedmiotem negocjacji, ale będą podejmowane jednostronnie przez Komisję, czyli wobec krajów socjalistycznych (włącznie z Polską) będzie ona prowadziła tzw. autonomiczną politykę handlową. Oznaczało to, że Polska oraz inne kraje socjalistyczne w sytuacji braku międzypaństwowych umów regulujących ich stosunki handlowe musiały podporządkować się jednostronnym decyzjom Wspólnoty dotyczących wzajemnych kontaktów handlowych (Sulmicki, 1975). Ten tzw. stan bezumowny między Polską a EWG rozpoczął się 1 stycznia $1975 \mathrm{r}$.

\section{Stan bezumowny}

Przyczyn powstania stanu bezumownego między Polską a EWG należy szukać w stanowisku krajów RWPG wobec EWG. Kwestionowały one bowiem polityczne istnienie Wspólnoty jako organizacji ponadnarodowej. Państwa RWPG uważały, że należy zawrzeć umowę na szczeblu EWG-RWPG, która powinna określać ogólne zasady handlu, porozumienia bilateralne zaś miały ograniczać się do konkretnych rozwiązań technicznych. Projekt umowy przedstawionej im przez Komisję EWG kraje RWPG uznały za niekorzystny i stanowiący dla nich krok wstecz $\mathrm{w}$ porównaniu z poprzednio obowiązującymi umowami międzypaństwowymi. Stanowisko EWG w sprawie umowy handlowej sprowadzało się do tego, że miały być w niej uregulowane między organizacjami tylko kwestie kontaktów roboczych EWG-RWPG (Michałowska-Gorywoda, 1976). Chodziło głównie o wymianę informacji, szczegółowe kwestie handlu miały być natomiast przedmiotem uregulowań w umowach dwustronnych między Wspólnotą a poszczególnymi państwami RWPG. EWG nie uznawała również kompetencji organów instytucjonalnych RWPG do reprezentowania interesów handlowych ówczesnych państw socjalistycznych wchodzących w skład tego ugrupowania (Bożyk, 1977). Oba stanowiska były więc ze sobą sprzeczne i w tych kwestiach porozumień nie osiągnięto. Takie usztywnienie wzajemnych stosunków na osi EWG-RWPG rozpoczęte w 1975 r. trwało do końca 1985 r. W rezultacie tego w tzw. ogólnych stanowiskach handlo- 
wych zaistniał od 1 stycznia 1975 r. między Polską a EWG, a także między EWG a pozostałymi państwami socjalistycznymi stan bezumowny.

Funkcję zastępczą wobec wygasłych umów handlowych pełniły częściowo utrzymane w mocy umowy o współpracy gospodarczej, przemysłowej i naukowo-technicznej z krajami EWG. Polska posiadała takie umowy ze wszystkimi krajami członkowskimi EWG. Wspólnota bowiem nie miała wyłączności w zakresie regulowania tych spraw, tak jak miało to miejsce w sferze stosunków handlowych. $\mathrm{Z}$ natury rzeczy wymienione powyżej umowy mogły odnosić się tylko do niektórych aspektów wymiany handlowej. W rezultacie stosowania przez państwa EWG od 1975 r. autonomicznej polityki handlowej wobec krajów socjalistycznych, pod którą to nazwą należało rozumieć postanowienia w kwestii ceł, środków pozataryfowych, postanowień antydumpingowych oraz norm technicznych, sanitarnych i zdrowotnych (podejmowanych jednostronnie przez EWG) znalazły się one w sytuacji niekorzystnej (Gotz-Kozierkiewicz, 1975). Polska również odczuwała niedogodności wynikające z zaistniałego stanu rzeczy. W wyniku zaistniałego stanu bezumownego zostaliśmy pozbawieni możliwości wpływania na warunki dostępu naszego eksportu do rynków Wspólnoty. Nie mogliśmy również przeciwdziałać negatywnym skutkom wynikającym z ograniczeń eksportowych na rynki EWG.

\section{Porozumienia zawierane w okresie stanu bezumownego}

Aby uniknąć zaskoczenia jednostronnymi, jednoznacznie niekorzystnymi dla naszego handlu zagranicznego decyzjami, strona polska postarała się o zawarcie z EWG odpowiednich porozumień, zwanych umowami sektorowymi. Idea tego rodzaju postepowania wywodziła się z przeświadczenia, że jeśli nie zaczniemy rozmawiać ze Wspólnotą przynajmniej w liczących się dziedzinach naszego eksportu (tekstylia, stal) uważanych przez EWG za „wrażliwe”, zostaniemy postawieni w przymusowej sytuacji dostosowania się do jednostronnych decyzji Wspólnoty. Duża aktywność pod koniec lat 70. w kontaktach między Polską a EWG przejawiała się głównie w zakresie porozumień o dobrowolnym ograniczaniu eksportu, które przyjmowały najczęściej formę umów sektorowych. Były to porozumienia dwustronne (w przeciwieństwie do narzuconych jednostronnie autonomicznych ograniczeń ilościowych), których idea sprowadzała się do wymuszenia na eksporterze przez Wspólnotę zobowiązania do „dobrowolnego” przestrzegania pewnych kwot ilościowych lub wartościowych wywozu, w zamian za obniżkę opłat wyrównawczych, upust w stosunku do dopuszczalnej w EWG minimalnej ceny importowej czy też w zamian za stały, wynegocjowany procent wzrostu kwot eksportowych 
(Zabielski, 1977). Ze szczegółowej analizy takich porozumień wynikało, że ich zawieranie było znacznie bardziej korzystne dla interesów polskiego eksportu, niż pozostanie $\mathrm{w}$ stanie umownym, tj. podporzadkowanie się ogólnym zasadom importu Wspólnoty. Wychodząc z tego założenia, Polska podpisała z EWG w 1978 r. dwie umowy dotyczące tekstyliów i stali, a w 1980 r. zawarła umowę w sprawie żywca i mięsa baraniego (Antowska-Bartosiewicz, 1979). Pierwsze porozumienie zawarli przedstawiciel Rady Ministrów Wspólnoty oraz dyrektor departamentu Ministerstwa Handlu Zagranicznego, a dwie pozostałe stali przedstawiciele Polski oraz EWG przy GATT.

\section{Umowa tekstylna}

Pierwsza umowa sektorowa dotycząca eksportu tekstyliów z Polski do EWG, podpisana w 1978 r. obowiązywała cztery lata. W 1986 r. zawarto trzecie już tego typu porozumienie na lata 1987-90. Umowy tekstylne oparte były na zasadach funkcjonowania Porozumienia Wielowłóknowego GATT (Multifibre Agreement GATT). Korzyści z zawarcia umowy tekstylnej były dla Polski następujące:

a) stały wynegocjowany procent wzrostu kwot eksportowych, czego nie gwarantował autonomiczny system importu z EWG. W umowie z 1986 r. wynosił on 3,9\% rocznie i zależał od stopnia wrażliwości rynkowej poszczególnych kategorii tekstylnych;

b) zapewnienie polskim eksporterom stabilnych warunków dostępu do rynku Wspólnoty w okresie obowiązywania umowy, co miało znaczenie w działalności marketingowej oraz w określaniu struktury produkcji (Machlup, 1983).

Strona polska zobowiązała się do nieprzekraczania pewnych umownych wielkości w eksporcie tekstyliów i odzieży. W związku z tym musieliśmy przestrzegać kontyngentów ilościowych - współrynkowych (dla całej EWG) i krajowych (odnoszących się do poszczególnych krajów). W ramach ostatniej umowy liczbę kontyngentów ograniczono do 33 kategorii artykułów tekstylnych zebranych w trzech grupach. Łącznie występowało 268 kontyngentów krajowych, ponieważ nie wszystkie kraje członkowskie EWG wprowadziły ograniczenia importu w odniesieniu do wszystkich kategorii. Pozostałe kategorie tekstyliów (istniało ich w IFA 161) nieobjęte kontyngentowaniem mogły również podlegać samoograniczeniom, gdyż:

a) polskie dostawy wyrobów tekstylnych przewyższały o $2 \%$ w globalnym imporcie danej kategorii do EWG; 
b) polskie dostawy przewyższały określony udział w imporcie danej kategorii tekstyliów do konkretnych krajów członkowskich EWG.

\section{Umowa stalowa}

Umowa została podpisana przez Polskę i EWG w 1978 r. i dotyczyła eksportu polskich wyrobów hutniczych. Była ona odnawiana co rok, a jej warunki zależały od koniunktury na rynku stali. Porozumienie to dało polskim eksporterom możliwość oferowania produktów po cenach niższych o tzw. cenową marżę penetracyjną (o 4\% dla stali specjalnej i o 6\% dla stali zwykłej) od cen importowych (tzw. bazowych) wyznaczonych przez Wspólnotę dla krajów trzecich. Polska musiała jednak przestrzegać globalnych kontyngentów dla EWG, kontyngentów krajowych, a także subkwot na określone produkty krajowe. Polscy eksporterzy zobowiązali się również umieszczać w kontraktach z krajami nienależącymi do EWG klauzulę zakazującą reeksportu polskich wyrobów hutniczych do EWG. Globalne kwoty importowe były co roku renegocjowane. To samo dotyczyło subkwot krajowych (ich wielkości i struktury). Porozumienie stalowe do końca 1984 r. przyniosło Polsce korzyści w wysokości ok. 38,5 mln dol.

\section{Porozumienie w sprawie eksportu żywca i mięsa baraniego}

Zostało zawarte w 1981 r. i obowiązywało do 1984 r. z możliwością automatycznego przedłużania, co było realizowane przez cały okres lat 80 . Dotyczyło ono eksportu przez Polskę do EWG żywych owiec, kóz oraz mięsa baraniego, jagnięcego i koziego zarówno świeżego, jak i chłodzonego. Począwszy od 1981 r. polscy eksporterzy mogli wysłać do Wspólnoty rocznie do 6 tys. ton wymienionego asortymentu, bez pobierania od nich opłat wyrównawczych, które obowiązałyby w stanie bezumownym. Wysokość tych opłat stosowanych równolegle z cłem była tak znaczna, że gdyby chcieć bez umowy o samoograniczeniu osiągnąć wartość eksportu uzyskaną przez Polskę w warunkach jej funkcjonowania w 1984 r. wynosząca ok. $15 \mathrm{mln}$ dol. trzeba byłoby podwoić wolumen dostaw. EWG prowadziła również nadzór nad cenami importu i polscy eksporterzy musieli przestrzegać pewnych cen minimalnych (Bossak, Kawecka-Wyrzykowska, 1984). Do końca lat 80. nie udało się polskim negocjatorom ustalić wyższego poziomu istniejącej kwoty importowej, chociaż możliwości naszego eksportu w tej dziedzinie były znacznie wyższe. Oprócz wymienionych typowych umów o samoograniczeniu Polska 
zawarła z EWG porozumienia zbliżone w swoim kształcie do nich, niebędące jednak ścisłymi umowami o samoograniczeniu. Należały do nich: porozumienie w sprawie eksportu bydła opasowego, porozumienie o eksporcie pulp i owoców mrożonych oraz o eksporcie kalmarów. W przypadku eksportu bydła opasowego zawarto w formie wymiany listów za pośrednictwem przedstawicielstw Polski i EWG przy GATT w kwietniu 1979 r. porozumienie, na mocy którego Polska zapraszana była każdej jesieni na konsultacje związane z ustaleniem przez EWG bilansu zapotrzebowania na wołowinę i bydło na rok następny. Rozpatrywano wtedy rozmiary potrzeb importowych EWG i możliwości eksportowe Polski (Dobroczyński, 1980). Mechanizm konsultacji mógł być wykorzystany w każdym innym terminie, jeśli któraś ze stron widziała taką konieczność. Umowa nie przewidywała ustalania kontyngentów dostaw dla eksporterów, w ramach ilości bydła opasowego eksportowanego przez Polskę obniżane były natomiast opłaty wyrównawcze według określonego schematu:

a) dla zwierząt o ciężarze $0-300 \mathrm{~kg}$ o $65 \%$, dla 16,5 tys. sztuk;

b) dla zwierząt o ciężarze 220-300 kg o 75\%, dla 110 tys. sztuk;

c) zwierzęta o większym ciężarze nie były eksportowane przez Polskę, gdyż ich przywóz do EWG wymagał uiszczenia pełnej opłaty wyrównawczej.

W sprawie eksportu pulp i owoców mrożonych zawarto z Komisją EWG rodzaj gentelmen's agreement, w którym obie strony zobowiązały się przeciwdziałać niekorzystnym tendencjom cenowym, wymieniać kwartalne informacje na ten temat oraz odnawiać ustalenia cenowe. Przewidziano także prawo do konsultacji w koniecznych przypadkach. Możliwości polskiego eksportu tej grupy towarów przekraczały rocznie wartość $30 \mathrm{mln}$ dol. Wspólnota zobowiązała się do niewprowadzania środków ochrony rynku wobec eksporterów z Polski, jeśli będą oni przestrzegać poziomu cen minimalnych ustalanych corocznie. W odniesieniu do kalmarów, które zostały objęte zakazem importu w wyniku dwukrotnego wzrostu ich dostaw do EWG z polskich statków dokonujących połowów na łowiskach Atlantyku, uzgodniono w ramach kontaktów technicznych między Komisją EWG a polskim Ministerstwem Handlu Zagranicznego i Rybexem, że polskie dostawy nie przekroczą 10 tys. ton rocznie oraz że ich ceny nie spadną poniżej określonego pułapu. Roczna wartość polskiego eksportu kalmarów do EWG przekroczyła w latach 80 . kwotę $8 \mathrm{mln}$ dol. Wszystkie powyższe umowy i porozumienia były zawierane w warunkach braku wspólnej bazy formalno-prawnej między Polską a Wspólnotą. Wykorzystywano w tym celu jedyne wspólne forum, jakie stanowił GATT. W negocjacjach na szczeblu RWPG-EWG panował impas i w rezultacie zostały one zawieszone do 1980 r. W październiku 1984 r. wznowiono je z inicjatywy krajów RWPG (Sołdaczuk, 1987). Dojście do władzy w Związku 
Radzieckim (Sekretarz generalny KC KPZR) Michaiła Gorbaczowa wraz z jego polityką otwarcia na świat oraz nowa pragmatyczna linia radzieckiej polityki zagranicznej przyniosły w rezultacie zmianę oficjalnego stanowiska RWPG wobec Wspólnoty wyrażającą się odstąpieniem od koncepcji zawarcia umowy na szczeblu EWG-RWPG, która miała określać zasady handlu i wzajemnego traktowania. Efektem długotrwałej tury rozmów między przedstawicielami RWPG i EWG było uzgodnienie między obiema stronami Wspólnej Deklaracji, której podpisanie nastąpiło 25 czerwca 1988 r. w Luksemburgu. Deklaracja ta miała charakter dokumentu politycznego i nie mówiła nic o konkretnych stosunkach gospodarczych poza stwierdzeniem o dążeniu obu stron do rozwijania współpracy gospodarczej w dziedzinach należących do ich odpowiednich kompetencji i będących przedmiotem wspólnego zainteresowania. Strony uznały też dalszy rozwój międzynarodowej współpracy gospodarczej za ważny czynnik rozwoju gospodarczego i postępu społecznego. Te bardzo ogólne zapisy wynikały z faktu, że EWG stała na stanowisku nieposiadania przez RWPG kompetencji do podejmowania decyzji gospodarczych w imieniu swoich członków. Rola Wspólnej Deklaracji polegała przede wszystkim na tym, że oznaczała ona normalizację stosunków politycznych między dwoma największymi w ówczesnej Europie organizacjami gospodarczymi, a także między poszczególnymi krajami bloku socjalistycznego a Wspólnotą. Do końca 1988 r. wszystkie europejskie kraje socjalistyczne uznały EWG. Brak takiego uznania był bowiem głównym hamulcem rozwoju wzajemnej współpracy gospodarczej (Taylor, 1989). Uzgodnienie Deklaracji stało się możliwe dzięki przemianom zachodzącym w całym bloku wschodnim oraz dzięki poprawie stosunków Wschód-Zachód. Deklaracja otworzyła drogę do normalizacji stosunków gospodarczych między EWG a Europą Środkowo-Wschodnią. W ślad za uznaniem EWG wszystkie europejskie kraje socjalistyczne uznały za możliwe zawarcie z nią umów handlowych. Rozmowy Polski z EWG rozpoczęły się w marcu 1989 r. w celu uzgodnienia i zawarcia układu handlowo-gospodarczego między naszym krajem a Wspólnotą (Kawecka-Wyrzykowska, 1989).

\section{Charakterystyka części handlowej umowy o handlu i współpracy gospodarczej Polska-EWG}

Umowa o handlu i współpracy gospodarczej została podpisana między Polską i EWG 19 września 1989 r. na 5 lat. Była ona trzecią z kolei umową po podpisanych wcześniej umowach między EWG a Węgrami i Czechosłowacją. Składała się ona z preambuły oraz czterech rozdziałów poświęconych w kolejności: handlowi 
i współpracy handlowej, współpracy gospodarczej, utworzeniu Komisji Mieszanej oraz postanowieniom ogólnym i końcowym. Cel umowy został sprecyzowany w preambule, w której możemy przeczytać, że „porozumienie to ma stworzyć korzystne warunki dla harmonijnego rozwoju i dywersyfikacji obrotów handlowych, jak też dla promocji współpracy handlowej i gospodarczej na zasadach równości, niedyskryminacji, dwustronnych korzyści i wzajemności”. Umowa obejmowała swymi postanowieniami w części dotyczącej współpracy handlowej wszystkie towary pochodzące z Polski lub EWG będące przedmiotem wymiany z wyjątkiem produktów podlegających traktatu ustanawiającego Europejską Wspólnotę Węgla i Stali (Wieczorek, 1989). Umowa również nie zmieniła postanowień zawartych w umowach zbiorowych dotyczących handlu produktami włókienniczymi i produktami rolnymi. Obie strony potwierdziły zobowiązanie wzajemnego przyznawania sobie Klauzuli Najwyższego Uprzywilejowania w handlu zgodnie z zasadami GATT oraz Protokołem przystąpienia Polski do GATT.

Wspólnota zdecydowała się w umowie znieść dyskryminacyjne ograniczenia ilościowe, które były stosowane wobec naszego eksportu. Miało to się stać do końca 1994 r. i nastąpić w trzech etapach. Dotyczyło to ok. 1600 towarów (według nomenklatury celnej EWG), z których $1 / 3$ stanowiły tzw. pozycje martwe, których nie wywoziliśmy wcale lub wywoziliśmy w bardzo małych ilościach. Kontyngenty obowiązujące dla tych towarów miały być zniesione w ciągu roku od podpisania układu. W latach 1990-1992 miały zostać zniesione kontyngenty na artykuły, których eksport dotychczas był wprawdzie objęty kwotami, ale kwoty te nie były wykorzystane w całości (lecz powyżej 50\%) przez nasz kraj. Do 31 grudnia 1994 r. miały przestać obowiązywać kontyngenty na pozostałe artykuły. W umowie o handlu między Polską a EWG uzgodniono także postanowienia dotyczące handlu rolnego (Zawadzka, 1996). Od 1 stycznia 1990 r. Wspólnota udzieliła Polsce obniżek ceł i opłat wyrównawczych na ok. 10 pozycji towarowych, których eksport w skali roku przekraczał wartość $200 \mathrm{mln}$ ECU. Korzyści z tego posunięcia dla strony polskiej oszacowano na ok. $5 \mathrm{mln}$ ECU. Ponieważ Polska w większości towarów rolnych objętych redukcją ceł i opłat wyrównawczych była ich głównym eksporterem wśród krajów trzecich na rynek EWG, to mimo że obniżki te zgodnie z Klauzulą Najwyższego Uprzywilejowania zostały rozciągnięta również na innych dostawców, były one dla nas szczególnie korzystne. Równocześnie Polska przyznała Wspólnocie na zasadzie wzajemności ulgi celne w eksporcie do naszego kraju 11 artykułów rolno-spożywczych, które nie miały substytutów krajowych. Obroty handlowe między stronami odbywały się według cen światowych. Umowa w części handlowej zawierała także postanowienia dotyczące klauzuli ochronnej, która znajdowała zastosowanie wówczas, gdy w handlu między Polską a EWG 
występowało tak duże zwiększenie eksportu którejś ze stron, że groziło to spowodowaniem poważnych strat dla producentów krajowych podobnych produktów lub produktów bezpośrednio konkurencyjnych (Misala, 1990). Każda ze stron miała wtedy prawo (po konsultacjach) podjąć środki przeciwdziałające tej akcji.

Postanowienie dotyczące arbitrażu w zakresie uregulowania sporów związanych z transakcjami w dziedzinie handlu zagranicznego zawieranymi przez spółki, przedsiębiorstwa i organizacje gospodarcze Polski i Wspólnoty stwierdzało, że strony popierały zasady arbitrażu opracowanego przez Komisję ONZ do spraw międzynarodowego prawa handlowego oraz arbitrażu każdego ośrodka prawnego państw-sygnatariuszy Konwencji o uznawaniu i wykonywaniu zagranicznych orzeczeń arbitrażowych przyjętej w Nowym Jorku 10 czerwca 1965 r. W części umowy poświęconej współpracy gospodarczej Polski i EWG uzgodniono, że polegać ona będzie na:

a) popieraniu wspólnej działalności i rozwijaniu takich działań jak: budownictwo, petrochemia, rolnictwo, górnictwo, energetyka, transport, telekomunikacja, ochrona środowiska, och rona zdrowia, szkolnictwo, nomenklatura i statystyka;

b) promowaniu przez Wspólnotę zmian strukturalnych w gospodarce polskiej w przemyśle i usługach w celu zwiększenia wymiany z EWG.

Umowa nie naruszała istniejących umów bilateralnych i nie zabraniała państwom członkowskim zawierania nowych umów w dziedzinie współpracy gospodarczej, jeśli zaistnieje taka potrzeba. Strony powołały również Komisję Mieszaną złożoną z przedstawicieli obu stron, której celem było czuwanie nad realizacją umowy i usuwanie problemów technicznych powstających w trakcie jej funkcjonowania. Zbierała się ona raz w ciągu roku w Warszawie i Brukseli. Umowa w sprawie handlu i współpracy gospodarczej między Polską i EWG stworzyła w sferze stosunków formalno-prawnych korzystne warunki eksportu na rynek EWG. Spośród umów zawartych do tego momentu przez europejskie państwa socjalistyczne, tj. Rumunię, Węgry i Czechosłowację była ona zdecydowanie najkorzystniejsza. Nie miała co prawda charakteru preferencyjnego, ale likwidowała dyskryminację polskich dostawców na rynek EWG oraz przyznawała naszemu krajowi ulgi w handlu rolnym. 


\section{Decyzja EWG z jesieni 1989 r. w sprawie warunków dostępu polskiego eksportu do rynku Wspólnoty}

Dodatkowymi czynnikami wzmacniającymi pozycję Polski na rynku EWG w porównaniu z innymi krajami, z którymi Wspólnota podpisała umowy niepreferencyjne, były trzy decyzje Rady Ministrów EWG z jesieni 1989 r. Pierwsza, podjęta 6 listopada 1989 r. przed wejściem w życie umowy o handlu i współpracy gospodarczej EWG-Polska, dotyczyła zniesienia ograniczeń ilościowych dyskryminujących polski eksport (Wieczorek, 1989). Zamiast znosić je do końca 1994 r. Rada zdecydowała, że przestaną one obowiązywać od 1 stycznia 1990 r. Wspólnota uczyniła ten gest w związku z demokratyzacją życia politycznego i procesem reform społecznych rozpoczętych w Polsce, również dla poparcia przemian zachodzących w naszym kraju. Temu celowi służyła także kolejna decyzja podjęta przez Radę Ministrów 27 listopada 1989 r. o zawieszeniu na okres jednego roku ilościowych ograniczeń niedyskryminacyjnych (stosowanych również w stosunku do innych krajów) dla polskiego eksportu. Tego samego dnia Rada zdecydowała, aby od 1 stycznia 1990 r. na Polskę oraz Węgry rozciągnąć na 5 lat System Powszechnych Preferencji Celnych. Systemem Preferencji przyznanych Polsce zostały objęte wszystkie towary przemysłowe (bez artykułów stalowych), półwyroby oraz niektóre artykuły rolne. Pod warunkiem jednakże, że zostały one całkowicie wyprodukowane lub w znacznym stopniu przetworzone w Polsce, co było określane przez tzw. reguły pochodzenia. Ogólna zasada zastosowana przy objęciu danego kraju systemem preferencji celnych polegała na niepobieraniu lub znacznej obniżce cła przez kraj przyznający preferencje (EWG) na importowane towary z kraju beneficjenta (Polska). Korzyści w postaci przyznania Polsce Systemu Preferencji Celnych na przykładzie 10 produktów rolno-spożywczych prezentuje poniższa tabela. 
Tabela 1. Towary, na które EWG obniżyła stawki celne lub opłaty wyrównawcze przy imporcie z Polski na mocy umowy o handlu i współpracy gospodarczej oraz w ramach GSP

\begin{tabular}{|c|c|c|c|}
\hline Nazwa towaru & $\begin{array}{l}\text { Automatyczna } \\
\text { stawka celna } \\
\text { lub opłata } \\
\text { wyrównawcza } \\
\text { w taryfie celnej } \\
\text { EWG }(\mathbf{w} \%)\end{array}$ & $\begin{array}{c}\text { Stawka celna } \\
\text { lub opłata } \\
\text { wyrównawcza } \\
\text { z umowy } \\
\text { handlowej Polska- } \\
\text {-EWG (w \%) }\end{array}$ & $\begin{array}{c}\text { Stawka celna } \\
\text { lub opłata } \\
\text { wyrównawcza } \\
\text { do realizacji } \\
\text { w ramach GSP } \\
(\mathbf{w} \%)\end{array}$ \\
\hline $\begin{array}{l}\text { 1. Konie rzé́ne } \\
\text { 2. Kaczki skubane } \\
\text { i patroszone, 63\% } \\
\text { - świeże/chłodzone } \\
\text { - mrożone } \\
\text { 3. Gęsi skubane } \\
\text { i patroszone, } 75 \% \\
\text { - świeże/chłodzone } \\
\text { - mrożone } \\
\text { 4. Elementy gęsie bez kości, } \\
\text { poza podrobami } \\
\text { - świeże/chłodzone } \\
\text { - mrożone } \\
\text { 5. Piersi gęsie i ich elementy } \\
\text { nieodkostnione } \\
\text { - świeże/chłodzone } \\
\text { - mrożone } \\
\text { 6. Uda gęsie i ich elementy } \\
\text { nieodkostnione } \\
\text { - świeże/chłodzone } \\
\text { - mrożone } \\
\text { 7. Grzyby kurki } \\
\text { 8. Truskawki mrożone } \\
\text { bez cukru } \\
\text { 9. Wędliny i kiełbasy suche } \\
\text { do krojenia, gotowane } \\
\text { lub inne niż z wątroby } \\
\text { 10. Inne przetwory } \\
\text { z mięsa lub podrobów } \\
\text { wieprzowych, w tym } \\
\text { ze słoniny i wszelkich } \\
\text { tłuszczy zawierających } \\
\text { 80\% lub więcej } \\
\text { mięsa poza szynkami, } \\
\text { polędwicami, krzyżową } \\
\text { łopatką i mięsem } \\
\text { wołowym } \\
\end{array}$ & $\begin{array}{l}18 \\
18 \\
10 \\
20 \\
\\
21\end{array}$ & $\begin{array}{c}2,5 \\
\text { Obniżka opłaty } \\
\text { wyrównawczej o } 10 \% \\
\text { dla } 1500 \text { ton } \\
\text { Obniżka opłaty } \\
\text { wyrównawczej o } 20 \%\end{array}$ & $\begin{array}{c}\text { j.w. } \\
\text { j.w. } \\
0 \\
13 \\
\text { Obniżka opłaty } \\
\text { wyrównawczej o } 50 \% \\
\text { dla } 1500 \text { ton } \\
\text { Obniżka opłaty } \\
\text { wyrównawczej o } 50 \% \\
\text { dla } 6800 \text { ton }\end{array}$ \\
\hline
\end{tabular}

Źródło: opracowanie własne na podstawie Taryfy celnej EWG, 1990. Załącznik IV do Umowy Polska-EWG 
Tabela 2. Towary rolne spożywcze, na które Polska obniżyła stawki celne przy imporcie z EWG

\begin{tabular}{|l|c|}
\hline \multicolumn{1}{|c|}{ Nazwa towaru } & \multicolumn{1}{|c|}{$\begin{array}{c}\text { Stawka celna } \\
\text { ad valorem (w \%) }\end{array}$} \\
\hline 1. Sery typu: Danbo, Fontal, Fontina, Gouda, Havarti, Maribo, \\
$\begin{array}{l}\text { Samsoe, Edam } \\
\text { 2. Pomarańcze typu: Navela, Nabelines, Vernas, Valencia lates, } \\
\quad \text { Maltese, Shamoutis ovalia, Trovita, Hamlina poza czerwonymi } \\
\text { i półczerwonymi }\end{array}$ & 10 \\
3. Kawa palona niepozbawiona kofeiny & 10 \\
4. Olej surowy sojowy, gęsty w opakowaniach ponad 1 kg & 5 \\
ub płynny dla celów spożywczych & 3 \\
5. Gliceryna surowa & 6 \\
6. Gliceryna surowa lub syntetyczna & 6 \\
7. Odżywki dla dzieci & 5 \\
8. Sok pomarańczowy o gęstości równej lub wyższej 1,33 g/cm ${ }^{3}$. & 8 \\
9. Wermuty i inne wina gronowe z dodatkiem ziół i produktów & 10 \\
aromatycznych & 50 \\
10. Alkohol etylowy, niedenaturowany o minimalnej mocy 80\% & 60 \\
11. Whisky inna niż „Burbon” w pojemnikach 2 1 lub mniejszych & \\
\hline
\end{tabular}

Źródło: opracowanie własne na podstawie Załącznika V do umowy Polska-EWG oraz Taryfy celnej EWG na 1990 r.

\section{Przyczyny podjęcia negocjacji w sprawie umowy o stowarzyszeniu}

Traktat Rzymski z 1957 r. powołujący do życia Europejską Wspólnotę Gospodarczą już w pierwszych słowach mówił o stworzeniu podstaw coraz ściślejszej współpracy, która usuwając bariery dzielące Europę, miała stymulować postęp gospodarczy i społeczny krajów wchodzących w skład powstałego ugrupowania gospodarczego, prowadzić do jedności politycznej i ekonomicznej opartej na zintegrowanym rynku ze swobodnym przepływem towarów, usług, ludności i kapitału (Tinbergen, 1954). Mimo że od podpisania Traktatu Rzymskiego minęło już wówczas 30 lat, wizja o prawdziwie zintegrowanym rynku w EWG jak dotąd nie spełniła się. W związku z tym Komisja Wspólnot Europejskich opracowała w 1985 r. pakiet propozycji dotyczących środków i terminów realizacji idei utworzenia do końca 1992 r. w pełni jednolitego rynku w EWG. Projekt ten znany jako „Biała Księga” został zaakceptowany przez Radę Wspólnoty. Jednolity Akt Europejski będący uzupełnieniem Traktatu Rzymskiego w tej kwestii, ratyfikowany przez parlamenty wszystkich krajów EWG, wszedł w życie 1 lipca 1987 r. W ten sposób proces integracji rozpoczęty przed laty nabrał nowego dynamizmu. 
$\mathrm{Na} 1992$ r. zaplanowano utworzenie w Europie Zachodniej wspólnego rynku EWG o swobodnym przepływie towarów, usług, ludności i kapitału. Dwunastka europejska miała stać się w niedalekiej przyszłości nowym jakościowo ugrupowaniem integracyjnym. Sytuacja ta sprawiła, że partnerzy handlowi Wspólnoty zaczęli wyrażać obawy na temat możliwości wzmocnienia przez ugrupowanie barier zewnętrznych (Synowiec, 1991). W związku z tym podjęli działania mające na celu zapobieżenie ewentualnym negatywnym skutkom pogłębienia procesów integracyjnych, m.in. państw EFTA.

Kraje socjalistyczne wchodzące w skład RWPG, dla których Wspólnota była odbiorcą ponad 50\% eksportu kierowanego do krajów kapitalistycznych znalazły się wobec dylematu, jak sprostać wymaganiom zintegrowanego rynku. Ogłoszenie Jednolitego Aktu Europejskiego oraz deklaracja państw EWG i EFTA na temat stworzenia Europejskiej przestrzeni ekonomicznej sprawiły, że realna stała się możliwość zepchnięcia państw RWPG do roli marginalnego partnera, jeśli kraje wchodzące w jej skład nie podjęliby szeregu działań mających na celu sprostanie zachodniej konkurencji (The future of relations, 1990). Tymczasem przemiany, które rozpoczęły się w tym rejonie Europy, spowodowały, że między Europejską Wspólnotą Gospodarczą a krajami socjalistycznymi możliwe stało się nawiązanie zupełnie nowych jakościowo stosunków gospodarczych. Do zmian tych, mających rewolucyjny charakter, zaliczyć należy:

a) zmianę systemu gospodarczego krajów Europy Środkowo-Wschodniej z centralnie planowanego na system gospodarki rynkowej oraz oparcie systemu politycznego tych państw na zasadach demokracji i pluralizmu;

b) koniec istnienia NRD przez przyłączenie tego państwa do RFN, a w konsekwencji powiększenie się Wspólnoty Europejskiej;

c) rozwiązanie Układu Warszawskiego oraz Rady Wzajemnej Pomocy Gospodarczej;

d) dezintegracja Związku Radzieckiego oraz powstanie niezależnych państw w miejsce dawnych republik nadbałtyckich.

\section{Podsumowanie}

Po podpisaniu w 1989 r. umowy handlowej między Polską a Wspólnotą Europejską rząd polski podjął staranie o nawiązanie maksymalnie szerokiej współpracy z Europejską Wspólnotą Gospodarczą. Stało się to możliwe w wyniku zmian dokonujących się na naszym kontynencie (Domański, 1989). Dla Polski integracja z Europejską Wspólnotą Gospodarczą stała się koniecznością zarówno ze 
względów ekonomicznych (spadek handlu ze Związkiem Radzieckim i innymi krajami socjalistycznymi oraz stałe przesuwanie się polskiego handlu na Zachód), jak też ze względów politycznych (wsparcie przemian politycznych zachodzących w naszym kraju przez państwa EWG oraz zabezpieczenie przed skutkami rozpadu ZSRR). Powstanie Zjednoczonej Europy w 1992 r., której granice wyznaczała ówczesna granica polsko-niemiecka, sprawiła, że zapewnienie dostępu do jej olbrzymiego rynku było warunkiem rozwoju gospodarczego Polski, zwłaszcza wobec perspektyw znacznego ograniczenia możliwości zbytu naszych wyrobów na Wschodzie (Oręziak, 1992, 6-30). Droga Polski do EWG wiodła przez status stowarzyszenia do pełnego członkostwa. Stowarzyszenie było bowiem alternatywą dla kraju słabiej rozwiniętego gospodarczo, który nie byłby w stanie sprostać obowiązkom pełnego członkostwa i w pełni otworzyć własny rynek dla silniejszych konkurentów. Korzyści dla Polski z uzyskania statusu państwa stowarzyszonego z EWG polegałyby przede wszystkim na zdynamizowaniu gospodarki i włączeniu jej do systemu europejskiego. Po okresie dostosowania reguł handlu, rynku kapitałowego oraz usług do tych panujących w rozwiniętych systemach gospodarki europejskiej, powstały warunki przynajmniej ze strony Polski do pełnej akcesji na rynki Wspólnoty.

Wychodząc z tych założeń strona polska złożyła w maju 1990 r. w Brukseli oficjalny wniosek o rozpoczęcie negocjacji o stowarzyszeniu ze Wspólnotą Europejską, poparty projektem tejże umowy (Mulewicz, 1990). W dniu 22 grudnia $1990 \mathrm{r}$. Komisja otrzymała mandat od Rady Ministrów do prowadzenia oficjalnych rozmów z polskim rządem na temat przyszłego stowarzyszenia. Kolejnych 6 rund negocjacji, które odbywały się do połowy lipca 1991 r., dały w rezultacie uzgodnienie ok. 70\% treści umowy. Pragnieniem strony polskiej było, aby rokowania rozpoczęły się w połowie 1991 r., tak aby po sześciu miesiącach procesu ratyfikacyjnego umowa weszła w życie z początkiem 1992 r. Szósta runda negocjacji pokazała jednak, że termin podpisania umowy zostanie odsunięty w czasie. Następna runda rokowań w sprawie stowarzyszenia została początkowo przesunięta na początek października, gdyż dopiero pod koniec września Komisja miała otrzymać od Rady Ministrów poszerzony mandat negocjacyjny. Wydarzenia w ZSRR w sierpniu $1991 \mathrm{r}$. zmieniły dość poważnie klimat polityczny w stosunkach Wspólnoty Europejskiej z krajami Europy Środkowo-Wschodniej. W wypowiedziach przedstawicieli Komisji Wspólnot podkreślano konieczność przyspieszenia negocjacji na temat stowarzyszenia tych krajów i ponownego przeanalizowania stanowiska „dwunastki” wobec jej ewentualnego rozszerzenia się. Poza uzgodnieniami natury gospodarczej w umowie o stowarzyszeniu niezwykle ważne było w opinii niektórych polityków Wspólnoty znalezienie sposobu na wzmocnienie tożsamości poli- 
tycznej poszczególnych krajów budujących system demokracji rynkowej z Europą Zachodnią.

Na spotkaniu ministrów spraw zagranicznych krajów członkowskich wspólnot w Hadze 20 sierpnia 1991 r. potwierdzono oficjalnie w związku z puczem w ZSRR pragnienie szybkiego sfinalizowania porozumień o stowarzyszeniu z Polską, Czechosłowacją i Węgrami. Strona polska poczyniła pewne kroki zmierzające do możliwie szybkiego zawarcia umowy o stowarzyszeniu z EWG. Służyły temu m.in. listy prezydenta Lecha Wałęsy w tej sprawie przekazane ambasadorom krajów „dwunastki” oraz kontakty Ministerstwa Spraw Zagranicznych z wysokimi urzędnikami Komisji.

\section{Bibliografia:}

Antowska-Bartosiewicz, I. (1979). Integracja rynków kapitatowych w EWG a stosunki kredytowe Wschód-Zachód. Warszawa: Instytut Finansów.

Balassa, B. (1962). The Theory of Economic Integration. London: George Allen and Unwin.

Balassa, B. (1968). Przyczynek do integracji gospodarczej. W: Z problemów integracji gospodarczej. Warszawa: PWE.

Bossak, J., Kawecka-Wyrzykowska, E. (1984). Wspótczesna gospodarka światowa. Struktura i tendencje rozwoju. Warszawa: SGPiS.

Bożyk, P. (1972). Korzyści z międzynarodowej specjalizacji. Warszawa: PWE.

Bożyk, P. (1977). Wspótpraca gospodarcza krajów RWPG. Warszawa: PWE.

Dobroczyński, M. (1980). Europejska wspótpraca gospodarcza. Warszawa: PWE.

Domański, G. (1989). Umowa ramowa na tle prawa niektórych państw EWG i Polski. Warszawa: Wydawnictwo Prawnicze.

Gotz-Kozierkiewicz, D. (1975). Podatki w Europejskiej Wspólnocie Gospodarczej. Warszawa: PWE.

Kawecka-Wyrzykowska, E. (1989). Zmiany w dostępie do rynku EWG w świetle umowy o handlu oraz wspótpracy handlowej i gospodarczej między Polską i EWG. Warszawa: IKiCHZ.

Łychowski, T. (1968). Międzypaństwowe umowy gospodarcze. Warszawa: PWE.

Machlup, F. (1983). Integracja gospodarcza-narodziny i rozwój idei. Warszawa: PWN.

Michałowska-Gorywoda, K. (1976). Czynniki intensyfikacji wspótpracy gospodarczej pomiędzy krajami RWPG i krajami EWG. Warszawa: SGPiS.

Misala, J. (1990). Teorie międzynarodowej wymiany gospodarczej. Warszawa: PWN.

Mulewicz, J. (1990). Utworzenie wspólnego rynku EWG w 1992 r. a ogólnoeuropejska wspótpraca gospodarcza. Warszawa: CINTiE.

Oręziak, L. (1992). Główne założenia przekształcenia EWG w unię gospodarczą i walutową. Handel Zagraniczny, 3, 6-30.

Sołdaczuk, J. (1987). Wspótczesna gospodarka światowa. Struktura, mechanizm, tendencje. Warszawa: PWE. 
Sulmicki, J. (1975). Perspektywy wspótpracy polsko-brytyjskiej po przystąpieniu Wielkiej Brytanii do EWG (do 1980 r.). Warszawa: SGPiS.

Synowiec, E. (1991). Stosunki handlowe Polski ze Wspólnota Europejska u progu lat 90-tych. Warszawa: Fundacja im. F. Eberta.

Taylor, C. (1989). 1992 the Facts and Challenges. London: The Industrial Society.

The Future of Relations between EEC and Eastern Europe (1990). Club de Bruxelles.

Tinbergen, J. (1954). International Economic Integration. Amsterdam-Brussel: Elsevier.

Wieczorek, J. (1989). Dostęp polskiego eksportu do EWG w świetle klauzul ochronnych. Warszawa: IKiCHZ.

Wieczorek, J. (1989). Znaczenie środków i barier pozataryfowych dla polskiego eksportu na rynek rozwiniętych krajów kapitalistycznych. Warszawa: SGPiS.

Zabielski, K. (1968). Integracja walutowa i finansowa w Europejskiej Wspólnocie Gospodarczej. Warszawa: Instytut Finansów.

Zabielski, K. (1977). Założenia unii walutowej EWG i trudności jej realizacji. Studia Finansowe, 24, 176-208.

Zawadzka, Z. (1996). Europejska Unia Gospodarcza i Walutowa - przygotowania do trzeciego etapu, Bank i Kredyt, 4, 27-33. 